\title{
Trade Preferences to Small Developing Countries and the Welfare Costs of Lost Multilateral Liberalization
}

\author{
Nuno Limão and Marcelo Olarreaga
}

\begin{abstract}
The proliferation of preferential trade liberalization over the last 20 years has raised the question of whether it slows multilateral trade liberalization. Recent theoretical and empirical evidence indicates that this is the case even for unilateral preferences that developed countries provide to small and poor countries, but there is no estimate of the resulting welfare costs. This stumbling block effect can be avoided by replacing the unilateral preferences with a fixed import subsidy, which generates a Pareto improvement. More importantly, this paper presents the first estimates of the welfare cost of preferential liberalization as a stumbling block to multilateral liberalization. Recent estimates of the stumbling block effect of preferences with data for 170 countries and more than 5,000 products are used to calculate the welfare effects of the European Union, Japan, and the United States switching from unilateral preferences for least developed countries to an import subsidy scheme. In a model with no dynamic gains to trade, the switch produces an annual net welfare gain for the 170 countries that adds about 10 percent to the estimated trade liberalization gains in the Doha Round. It also generates gains for each group: the European Union, Japan, and the United States (\$2,934 million), least developed countries ( $\$ 520$ million), and the rest of the world (\$900 million).
\end{abstract}

One pillar of the multilateral trading system is nondiscrimination across trading partners: the most favored nation (MFN) principle in the first article of the General Agreement on Tariffs and Trade. But nearly all World Trade Organization (WTO) members also participate in preferential trade agreements. The

Nuno Limão is an assistant professor of economics at the University of Maryland; his email address is limao@econ.umd.edu. Marcelo Olarreaga is a senior economist at the World Bank; his email address is molarreaga@worldbank.org. Both authors are affiliated with the Centre for Economic Policy Research. They thank Stephanie Aaronson, Piyush Chandra, Bernard Hoekman, Kyle Bagwell, George Bermann, Bill Davy, Aaditya Mattoo, Petros Mavroidis, Stefano Inama, Chris Stevens, Alan Winters, three anonymous referees, and participants of the seminar on the World Trade Organization and developing countries at Columbia Law School for helpful comments and discussions. They also thank the U.K. Department for International Development for financial support. A supplemental appendix to this article is available at http://wber.oxfordjournals.org/. 
potential for preferential trade agreements to be a stumbling block to multilateral trade liberalization (MTL) was an important concern during the Uruguay Round (Bhagwati 1991). This article quantifies the welfare effects of the more recent concern during the Doha Round that even unilateral trade preferences provided to small and poor developing countries can slow multilateral liberalization by the large developed countries that provide them. This problem prompted the International Monetary Fund (IMF) to create a special lending program aimed at developing countries "to mitigate concerns... that their balance of payments positions could suffer, albeit temporarily, as multilateral liberalization changes their competitive position in world markets. Chief among these concerns is that broad-based tariff liberalization might erode the value of their preferential access to important export markets" (IMF 2004b). ${ }^{1}$

The concern with preference erosion could affect the level of liberalization, particularly in the Doha Round, for two reasons. First, preference beneficiaries oppose MFN liberalization by countries that grant preferences. Even though erosion is critical only for a specific set of goods and countries, many other countries perceive such losses to be important. These countries can influence the current round because it was designated a "development round," creating the expectation that it would benefit developing countries. ${ }^{2}$ Second, developed countries providing preferences may want to maintain them because they can be used as a side payment for cooperation on nontrade issues. Here are two examples. First, in 2000 the European Commission argued that a cut in its price support for sugar was untenable because it would reduce income for developing countries that export sugar to the EU under preferences (European Commission 2000). Second, the United States recognizes that its MFN tariff reductions hinder its ability to extract concessions in terms of enforcing labor, environmental standards, and the like from countries that export under a preference to the United States (Mendelowitz 1994).

1. See also IMF (2004a). According to the WTO's director-general, the IMF's program is "a welcome contribution to the Doha Round, in particular to attaining ambitious market access results" (Panitchpakdi 2004). For an interesting discussion, see Winters (2004). The possibility that preference erosion would reduce MFN liberalization was actually noted long ago; it was a concern voiced by opponents of the Generalized System of Preferences when it was originally proposed (Johnson 1967).

2. This points to the importance of further research and dissemination of basic facts about gains from preferences. There is some debate regarding the effectiveness of preferences in generating additional exports. Haveman and Shatz (2004) provide evidence that the unilateral preferences of the triad economies (the European Union (EU), Japan, and the United States) considerably increased their imports from least developed countries in 2000. Earlier estimates of the Generalized System of Preferences scheme are provided by Sapir (1981) for the Eu and by Sapir and Ludenberg (1984) for the United States. UNCTAD (2003), Hoekman, Michalopoulos, and Winters (2004), and Stevens and Kennan (2004) propose several recommendations to fully realize the net benefits of preferences for least developed countries, including ways to improve utilization rates, to relax and harmonize rules of origin, to increase the predictability of preferences by binding them in the WTO, and so on. Many of these recommendations also apply to the alternative of import subsidies proposed here. 
Limão (2002) provides a model in which preferences that are extended to small countries can cause large countries to maintain higher MFN tariffs. This stumbling block effect arises because of an important feature of EU and U.S. preference schemes: they require cooperation in nontrade issues such as labor and environmental standards, intellectual property protection, drug enforcement, immigration, and human rights. The appendix contains references to these and other side conditions in various preferential trade agreements. The preferential margins extended to small countries are often a payment for cooperation, which implies that a reduction in MFN tariffs that lowers the preferential margin will be resisted by both the country that receives preferences and the country that grants them. ${ }^{3}$

The following example illustrates the intuition behind the problem and the solution explored here. The U.S. MFN tariff on flowers is 10 percent, but Colombia can export them to the United States at a preferential tariff equal to zerothat is, it has a 10 percent preference margin in the United States. If the United States set its MFN tariff on flowers equal to zero in the Doha Round, it would be unable to provide a preference margin to Colombia to extract cooperation on nontrade issues. Thus, the model predicts that the United States will not reduce this MFN tariff to zero. There is a simple solution to this problem: allow a preferential import subsidy set at a fixed rate, for example, at the level of the current preference margin, 10 percent. If the U.S. charges the MFN tariff on Colombian flowers but pays a fixed subsidy rate of 10 percent to the Colombian producers, all participants are initially indifferent. But the United States could then maintain the fixed subsidy rate and reduce its MFN tariff without the opposition that results from preference erosion and the U.S. desire to extract cooperation through preferences.

In this article the welfare costs of preferences in terms of lost MTL are calculated using the recent estimates of the stumbling block effect generated by U.S. preferences from Limão (2006). Similar estimates are obtained for the Eu by Karacaovali and Limão (2005). These estimates are combined with data for 170 countries and approximately 5,000 goods to provide the first welfare estimates of preferential trade agreements as a stumbling block. The welfare effects are calculated from a baseline MFN tariff reduction of 33 percent expected in the Doha Round relative to the subsidy counterfactual, which entails additional reductions by the triad economies (the Eu, Japan, and the United States). Given the results in Limão (2006), this additional liberalization is estimated to be about 8 percentage points for goods in which the triad economies offer preferences.

The focus here is on the preferences that the triad economies extend to least developed countries: a subset of preferential trade agreements that fit the assumptions of the theory well. Total annual welfare gains for the 48 least developed countries are estimated at $\$ 520$ million, with all countries but one

3. The fear that preferential trade agreements could be a stumbling block to MTL has generated a considerable theoretical literature but no consensus. See Bagwell and Staiger (1998), Krishna (1998), and Levy (1997). Winters (1999) provides an excellent review. 
gaining. The maximum gain is 6.7 percent of GDP, and the average is 0.38 percent. More important, the countries that most oppose MTL because of its preference erosion effect are estimated to gain the most from the switch. Welfare for the triad economies would increase by nearly $\$ 3$ billion a year, mainly because of the additional MFN tariff reductions allowed by the subsidy. For the same reason, the rest of the world experiences an annual welfare gain of $\$ 900$ million, which is important since one concern with preferential trade agreements is their costs on outsiders (Chang and Winters 2002). In relative terms, least developed countries as a group gain the most-over 0.5 percent of GDP a year. Similar gains arise for the least developed countries even if the subsidy causes only 2.8 percentage points of extra liberalization. Both the triad economies and the rest of the world continue to gain under this last scenario.

The aggregate annual welfare gain of $\$ 4,354$ million adds almost 10 percent to the gains that the model predicts from goods liberalization in the Doha Round without switching to subsidies-that is, relative to the baseline reduction of 33 percent. Moreover, this estimate is likely to be a lower bound of the stumbling block effect of preferential trade agreements. At one extreme, the concern with preference erosion could prevent the completion of the round, costing an additional $\$ 47$ billion.

Section I discusses recent theoretical and empirical evidence on how preferential treatment to small countries can generate a stumbling block and how it can be addressed by an import subsidy. In Section II the welfare effects are calculated. Section III addresses issues related to the implementation of the import subsidy. Section IV discusses the results. The appendix provides details on the theoretical model and discusses side conditions in preferential trade agreements. The supplemental appendix (available at http://wber.oxfordjournals.org/) provides details regarding the trade model used to simulate the effects, discusses data sources, and provides some descriptive statistics.

\section{Preferences as a Stumbling Block to MTL}

Preferential trade agreements can affect MFN tariffs through several channels. They can divert scarce negotiation resources and alter the number of negotiating parties and their bargaining power. In the context of unilateral preferences analyzed here, these effects are not as relevant as the concern with preference erosion. That concern has created an important stumbling block to MTL, as can be shown in a model where unilateral preferences are exchanged for cooperation in nontrade issues. The appendix provides such a model, based on Limão (2002), that shows two things. First, the unilateral preferences that large countries use can cause them to maintain higher multilateral tariffs even if those preferences are extended to countries that are small from a trade perspective. Second, an import subsidy resolves this problem. 
Three main criteria were used in choosing the counterfactual to analyze the cost of preferences as a stumbling block. It should remove the stumbling block, generate a Pareto improvement in the context of a well-defined model (so that it can be expected to gain the support of WTO members) and be simple enough to permit estimation and implementation.

When the import subsidy is designed to mimic trade preferences, it fulfills these criteria. Eliminating unilateral preferences or replacing them with direct transfers to reward cooperation would remove the stumbling block. However, eliminating preferences altogether is opposed by several countries so it is not as interesting a counterfactual. Cash transfers may not be the most efficient way to transfer resources to other countries, as the aid versus trade literature highlights, or to reward their cooperation. ${ }^{4}$ Political economy constraints that reduce the effectiveness of cash transfers relative to preferences are present in practice; otherwise it would be difficult to explain the existence of many preference schemes. For example, preferences may trigger investment in a particular sector and create a longer-lasting constituency when that country lobbies its government to do whatever is necessary to maintain the preferences. Lump-sum transfers could end up in anonymous bank accounts in Switzerland. So, as an alternative to preferences, the subsidy scheme may also dominate direct transfers.

Before the welfare costs of preferences are estimated, some direct evidence for preferential trade agreements as a stumbling block to MTL is provided that is subsequently used in the quantification. The model generates specific testable predictions. At an extreme, if the MFN tariff is zero, no tariff preference can be offered and so no preferential agreement is possible without subsidies. Therefore, to the extent that the EU and the United States value the cooperation in the side conditions of those agreements, reductions in MFN tariffs on products imported from the preferential partner are more costly than reductions in tariffs on other products.

Limão (2006) estimates the effect of U.S. preferential trade agreements on its MFN tariffs by exploring whether the effect occurs only with goods that the United States imports from its preferential trade agreement partners and not with goods that it imports only from the rest of the world. Using tariff data for more than 5,000 products, he finds that U.S. preferential trade agreements generated a stumbling block in the Uruguay Round. He estimates that the U.S. average reduction in MFN tariff for goods exported by any of its preferential trade agreement partners was about half that for other goods. The effect is stronger for products that are exported under all preferential trade agreements or that constitute larger shares of a given preferential trade agreement partner's exports to the United States. These estimates control for several determinants of U.S. tariff changes and carefully establish the direction of causality from the

4. Thus, the proposal here differs from the others that suggest temporary development assistance to the governments of developing countries that are hurt by preference erosion-for example, Hoekman (2004). See McCulloch and Pinera (1977) on the issue of trade and aid issue and Adam and O'Connell (2004) for a more recent analysis. 
preferential trade agreements to the MFN tariff changes using instrumental variables.

A switch by the triad economies to a subsidy after the Doha Round would cause them to reduce their tariffs by an additional 8.3 percentage points on the goods for which they provide preferences to least developed countries. This result is obtained by assuming a 33 percent MFN tariff liberalization in Doha on all goods-the average for developed countries in the Uruguay Round-and dividing it by a stumbling block factor of 80 percent calculated from Limão (2006). According to his estimates, the reduction in MFN tariffs for goods that the United States imports from its Generalized System of Preferences beneficiaries was only about 80 percent of what it would have been without such preferences. Thus under the subsidy scheme, triad economies' liberalization in goods where they provide a preference to least developed countries is estimated to be 41.3 percent, an additional 8.3 percentage points relative to the 33 percent baseline liberalization. The sensitivity of the welfare results is analyzed with respect to this estimate. ${ }^{5}$

Karacaovali and Limão (2005) provide similar estimates for the stumbling block effect that apply to the Eu's preferential trade agreements. The Eu average MFN tariff cut for goods exported by any of its preferential trade agreements was about half that for other goods. They also provide evidence that directly supports the use of an import subsidy as a solution when preferential tariffs are close to zero. Their model predicts that if the preferential tariff is positive, the MFN tariff can still be reduced without affecting the preference margin simply by lowering the preferential tariff by the same amount. This prediction is tested and confirmed for the eU, strongly supporting the argument that by removing the non-negativity constraint for preferential tariffs an import subsidy would indeed eliminate the stumbling block effect.

\section{Welfare Estimates of Preferences as a Stumbling BLOCK TO MTL}

This section first describes the methodology used to quantify the welfare costs of preferences as measured by the gains from switching to an import subsidy. Once

5. More specifically, the stumbling block factor is defined as $f=\left(\Delta t_{p} / t_{0}\right) /\left(\Delta t_{s} / t_{0}\right)$, where $\Delta t_{p} / t_{0}$ is the growth in the MFN tariffs of a triad economy when preferences are in place and $\Delta t_{s} / t_{0}$ is the growth when they are absent. Limão (2006) takes the changes in tariffs on the nonpreferential trade agreement good as the counterfactual for the outcome in preferential trade agreement goods if preferential trade agreements were absent and calculates $\Delta \ln \left(1+t_{p}\right) / \Delta \ln \left(1+t_{s}\right) \approx \Delta t_{p} / \Delta t_{s}=f$. Using his estimates leads to $\Delta \ln \left(1+t_{p}\right) / \Delta \ln \left(1+t_{s}\right)=(\tilde{a}+\rho *$ TOTLIB $+\phi) /(\tilde{a}+\rho *$ TOTLIB $)=0.8$. The variable TOTLIB represents the liberalization by U.S. partners, so $\rho$ captures the reciprocity effect; TOTLIB was 51.3 on average in his sample, so $\rho *$ TOTLIB $=0.018 *(-51.3)$. The estimates for $\rho=0.018$ and $\phi=0.658$ are from the last column of table 1 in Limão (2006), where he controls for the existence of other preferential trade agreements. Using his estimate for the Generalized System of Preferences in table 2, 0.74, yields $\tilde{a}=-2.53=0.658 /(0.74-1)$. The 95 percent confidence interval for the stumbling block factor described above is $(0.697,0.923)$, which is then used to calculate the high and low scenarios of additional liberalization of 14.3 percentage points and 2.8 percentage points in table 2 . 
the computed measures are conceptually clear, the estimation is standard. (The formal details of the estimation can be found in the supplemental appendix.) The empirical results are then discussed.

\section{Methodology}

First, the budgetary cost for each subsidy-granting country (SGC) is calculated. This is the amount paid to each subsidy-receiving country (SRC), which is an input into the welfare calculation and a measure that may preempt concerns with the budgetary costs of implementation. An import subsidy rate for each good and each SGC must be chosen. Here, this rate is the current preference margin, which provides a convenient benchmark to calculate welfare changes because the initial switch leaves all prices and quantities unchanged. Naturally, alternative subsidy rates are possible and would deliver different results. The first two columns of table 1 list the cost of this subsidy for all goods under current levels of tariffs and trade and under those predicted after the Doha Round, with MFN tariffs assumed to be 33 percent lower. The key budgetary measure is the cost of switching to the subsidy, which is obtained by subtracting the forgone tariff revenue under the current preferences (see column 3 of table 1).

Table 1. Budgetary Impact on Triad Economies of Switching to a Subsidy Scheme (\$ Millions)

\begin{tabular}{|c|c|c|c|c|}
\hline \multirow[b]{2}{*}{ Economy } & \multicolumn{2}{|c|}{ Cost of Subsidy } & \multirow[b]{2}{*}{$\begin{array}{l}\text { Cost of Switch } \\
\text { Post-Doha Most } \\
\text { Favored Nation } \\
\text { Tariff }^{c}\end{array}$} & \multirow[b]{2}{*}{$\begin{array}{c}\text { Preference Erosion } \\
\text { Post-Doha Most } \\
\text { Favored Nation } \\
\text { Tariff }^{\mathrm{d}}\end{array}$} \\
\hline & $\begin{array}{c}\text { Current Most } \\
\text { Favored Nation } \\
\text { Tariff }^{\mathrm{a}}\end{array}$ & $\begin{array}{c}\text { Post-Doha Most } \\
\text { Favored Nation } \\
\text { Tariff }^{\text {b }}\end{array}$ & & \\
\hline European Union & 669 & 674 & 208 & 441 \\
\hline Japan & 31 & 32 & 6 & 17 \\
\hline United States & 63 & 64 & 21 & 166 \\
\hline Total & 763 & 768 & 235 & 624 \\
\hline
\end{tabular}

Note: A decomposition of subsidies and preference erosion by subsidy-receiving countries is provided in appendix table A.1.

${ }^{a}$ Calculated using a subsidy rate for each good equal to the current preference margins in each subsidy-granting country using current prices, quantities, and most favored nation tariffs; see equation (S.1) in the supplemental appendix.

${ }^{\mathrm{b}}$ Assumes a 33 percent reduction in most favored nation tariffs by all World Trade Organization members; see equation (S.2) in the supplemental appendix.

${ }^{\mathrm{c}}$ Assumes a 33 percent reduction in most favored nation tariffs by all World Trade Organization members; see equation (S.3) in the supplemental appendix.

${ }^{\mathrm{d}}$ Uses current preferences and assumes a 33 percent reduction in most favored nation tariffs by all World Trade Organization members; see equation (S.12) in the supplemental appendix.

Source: Authors' analysis based on data discussed in the supplemental appendix. 
Second, the preference erosion measure is calculated for each preferencereceiving country in each preference-granting country market. If current preferences are maintained, this measure is simply the difference between the extra export revenue due to preferences before and after a 33 percent reduction in MFN tariffs without a subsidy. These values are listed in column 4 of table 1 and by country in appendix table A.1. ${ }^{6}$

Third, and most important, the welfare cost of preferences is calculated by country (table 2 and appendix table A.2). This is the additional welfare gain that would be obtained in the Doha Round if the triad economies switched to an import subsidy.

To calculate all three measures, we need an estimate of the changes in world prices and quantities imported and exported associated with the tariff reductions in the 170 countries in the sample. This is calculated by combining estimates of import demand and export supply elasticities with a simple trade model, which is described in detail in the supplemental appendix. A simple partial equilibrium model is employed for each six-digit tariff line in the Harmonized System. It assumes that each tariff line includes a homogeneous good and that the world market for each is in equilibrium. Neither substitution effects across goods nor income effects are modeled on the demand or the supply side. Although such effects could be incorporated here, recent work suggests that they have little impact on aggregate welfare gains. ${ }^{7}$ The aggregate welfare estimate here is similar to those generated using more complex computable general equilibrium models. ${ }^{8}$

\section{Empirical Results}

The focus here is on the preferences granted by the triad economies to 48 of the 49 least developed countries under the Generalized System of Preferences (data are not available to compute welfare gains for Kiribati). While these are not the only small countries that the triad economies offer preferences to, they form an interesting subgroup. Data on products at the six-digit harmonized standard level that receive preferences from triad economies

6. These preferences are not fully utilized (Inama 2003), so it is likely to also be the case under the subsidy. Therefore, the estimates of the cost of the subsidy and preference erosion are likely to be an upper bound for the true effects. However, this should not have a large effect on the net welfare calculations since the qualitative effect of imperfect utilization is similar under the subsidy and preference scenarios, and the net welfare effects are the difference between the two.

7. Hoekman, Nicita, and Olarreaga (2006) find that the world welfare gain from a 40 percent cut in MFN tariffs among WTO members is $\$ 51$ billion without cross-price effects and $\$ 59$ billion with them. This difference is statistically insignificant when they account for the standard errors associated with the measurement of the elasticities of import demand and export supply. Thus, the exposition of the model in the supplemental appendix is kept simple and clear by abstracting from cross-price effects.

8. For example, assuming a 33 percent liberalization for all wTO members leads to a yearly gain of about $\$ 47$ billion in our estimation. Francois, van Mejil, and van Tongeren (2005) estimate it to be $\$ 45$ billion when they apply a 50 percent cut in bound tariffs using a static computable general equilibrium model with constant returns to scale and with an Armington setup. 
Table 2. Annual Welfare Cost of Least Developed Country Preferences as a Stumbling Block

\begin{tabular}{|c|c|c|c|c|}
\hline \multirow[b]{2}{*}{ Economy } & \multirow[b]{2}{*}{ Share of GDP $(\%)$} & \multicolumn{3}{|c|}{$\$$ Millions $^{\mathrm{b}}$} \\
\hline & & Intermediate & Low & High \\
\hline Triad economies & 0.013 & 2,934 & 1,048 & 5,045 \\
\hline European Union & 0.027 & 2,336 & 849 & 4,023 \\
\hline Japan & 0.006 & 237 & 79 & 415 \\
\hline United States & 0.004 & 361 & 120 & 607 \\
\hline Least developed countries ${ }^{\mathrm{c}}$ & 0.518 & 520 & 513 & 526 \\
\hline Bangladesh & 0.36 & 176 & 173 & 179 \\
\hline Cambodia & 0.60 & 24 & 22 & 25 \\
\hline Lesotho & 2.09 & 18 & 18 & 18 \\
\hline Madagascar & 1.16 & 53 & 53 & 53 \\
\hline Malawi & 6.66 & 117 & 117 & 117 \\
\hline Maldives & 0.47 & 3 & 3 & 3 \\
\hline Mauritania & 0.61 & 6 & 6 & 6 \\
\hline Mozambique & 0.25 & 9 & 9 & 10 \\
\hline Myanmar & 1.23 & 20 & 19 & 21 \\
\hline São Tomé and Principe & 1.32 & 1 & 1 & 1 \\
\hline Senegal & 0.33 & 17 & 17 & 17 \\
\hline Sierra Leone & 0.65 & 5 & 5 & 5 \\
\hline Solomon Islands & 0.67 & 2 & 2 & 2 \\
\hline Tanzania & 0.32 & 30 & 30 & 30 \\
\hline Uganda & 0.11 & 7 & 7 & 7 \\
\hline Others & & 33 & 31 & 32 \\
\hline Rest of the world & 0.010 & 900 & 315 & 1,721 \\
\hline Total & 0.010 & 4,354 & 1,888 & 7,270 \\
\hline
\end{tabular}

Note: See appendix table A.2 for welfare estimates for other least developed countries. Estimates are based on equations (S.6) and (S.11) in the supplemental appendix.

${ }^{a}$ Intermediate welfare gains/GDP, where GDP is for 2002 and in current U.S. dollars.

${ }^{\mathrm{b}}$ Assumes a baseline reduction in most favored nation tariffs of 33 percent by all World Trade Organization members plus an additional amount by the triad economies in the products in which they provide preferences to least developed countries. The additional amount is 8.3 percentage points for intermediate, 2.8 percentage points for low, and 14.3 percentage points for high. These three figures are calculated using the estimates in Limão (forthcoming); 8.3 percentage points is calculated from a point estimate, and the extremes represent the 95 percent confidence interval. See the text for details.

${ }^{\mathrm{c}}$ The estimates for least developed countries are insensitive to different scenarios because most of their welfare gain is due to the avoided preference erosion under the 33 percent baseline common to all three scenarios.

Source: Authors' analysis based on data discussed in the supplemental appendix.

and on bilateral trade flows and MFN tariffs for all countries are used to calculate changes in prices and quantities due to liberalization. The import and export elasticities at the tariff line for every country are from the article by 
Kee, Nicita, and Olarreaga (2004). The exact data sources and years are in the supplemental appendix.

To provide an idea of trade coverage, we should note that in 2001-03 imports from least developed countries totaled on average $\$ 8$ billion for the eu, $\$ 1$ billion for Japan, and $\$ 7$ billion for the United States. According to UNCTAD (2003), 99.8 percent of dutiable EU imports from least developed countries are covered by preferences, as are 53 percent of Japanese imports and 44 percent of U.S. imports. Among least developed countries, Bangladesh and Cambodia are the top beneficiaries of EU and Japanese tariff preferences, and Madagascar and Malawi are the top beneficiaries of U.S. preferences.

The first column of table 1 lists that the cost of the subsidy for the triad economies is $\$ 763$ million without tariff reductions. This is equal to the tariff revenue currently forgone due to preferences, and it is borne mostly by the eu for three reasons. First, the Eu imports larger quantities from least developed countries. Second, EU preferences to least developed countries tend to be more generous, as seen in the supplemental appendix table S.1. Third, the EU MFN tariffs on the type of goods exported by least developed countries tend to be higher.

The second column of table 1 lists the amount of the subsidy after a 33 percent reduction in bound tariffs by all wTO members, $\$ 768$ million. It is higher than the currently forgone tariff revenue because exports from SRCs increase with the rise in world prices caused by the multilateral tariff reductions.

The third column of table 1 lists the estimates of the budgetary cost to triad economies implied by switching to the subsidy scheme. This cost arises because the tariff charged on imports from SRCs falls but the subsidy rate does not. Moreover, this shortfall applies to a larger value of imports because the MFN tariff reductions increase world prices. The total budgetary cost for the triad economies is only $\$ 235$ million, and the share borne by Japan and the United States is minimal. This value excludes the impact of any additional MFN tariff reduction that may be possible under the subsidy.

The fourth column of table 1 lists the preference erosion costs that preferencereceiving countries suffer in each triad economy market under a 33 percent reduction in MFN tariffs without a subsidy. These erosion costs would be much larger than the budgetary costs for the triad economies to move toward a subsidy. The least developed countries' loss is $\$ 624$ million, mostly in the EU market. Previous estimates were around $\$ 530$ million (for example, Subramanian 2004). There are two main reasons for the larger results here. First, the average estimated elasticity of export supply in least developed countries is 5 , which is larger than the value assumed by Subramanian for all goods, 1 . Second, the MFN tariffs here include ad valorem equivalents of specific tariffs, which leads to larger preference erosion. 
Estimates by country are summarized in appendix table A.1. They are calculated to help identify the countries that are, or should be, most opposed to MTL based on its impact on preference erosion. If these countries gain considerably by a switch to a subsidy, a large obstacle to liberalization may be removed. The three countries that would face the largest losses in absolute terms due to erosion are Bangladesh (\$202 million), Malawi (\$151 million), and Madagascar (\$63 million). The countries that face the largest losses in share of GDP are Malawi (8.6 percent), Lesotho (2.7 percent), and São Tomé and Principe (1.6 percent). The results also show that losses from preference erosion are concentrated, with 26 of 48 countries losing less than 0.1 percent of GDP.

The triad economies should not be opposed to switching to a subsidy simply because of the budgetary cost; switching would also allow further liberalization. table 2 summarizes estimates of the net welfare impact, including this extra liberalization by the triad economies on products subject to least developed country preferences. The focus here is on the intermediate estimates in the first two columns, which are based on an estimated additional 8.3 percentage points of liberalization; the sensitivity of the results to alternative estimates is discussed below. The annual gain for the triad economies is $\$ 2,934$ million, meaning that their governments should be in favor of switching. The largest gain, \$2,336 million, is for the EU; Japan would gain \$237 million and the United States \$361 million. ${ }^{9}$

The least developed countries also benefit from switching to the subsidy, with a total gain of $\$ 520$ million a year. The change in welfare is much larger for least developed countries when measured relative to GDP-about 50 times larger than that for the triad economies. There are 27 least developed countries that will see net welfare changes of less than 0.1 percent of GDP. And Djibouti experiences a marginal loss of $\$ 0.07$ million due to deteriorating terms of trade associated with liberalization.

Table 2 also lists the least developed countries that are among the top 10 countries that gain the most either in absolute value or as a share of GDP. These countries are also among those that gain the most per capita. The other 33 countries together gain only $\$ 33$ million. The largest absolute gains for individual least developed countries are for Bangladesh (\$176 million), Malawi (\$117 million), and Madagascar (\$53 million). The largest gains in share of GDP are for Malawi (6.7 percent), Lesotho (2.1 percent), and São Tomé and Principe (1.3 percent). Recall that these were the same countries that stood to lose the most from preference erosion. So if faced with a choice between the preference and the subsidy scheme, least developed countries should support the subsidy scheme and the additional MTL that it entails.

9. The results do not appear to be driven by specific products such as sugar, which, as discussed in the introduction, provides an important example of the effects discussed here. Excluding sugar, the welfare gain for the European is only $\$ 72$ million less. 
The aggregate welfare gain for least developed countries is lower than the preference erosion value in table 1 because preference erosion measures the change in export revenues and ignores any extra costs of production. For individual countries, the gains in table 2 may also be lower than the preference erosion effect in appendix table A.2 because additional MTL by the triad economies occurs in many goods, some of which the SRC may import, implying that it will face a deterioration in its terms of trade, for example, Djibouti and Rwanda.

The rest of the world gains $\$ 900$ million: 108 countries experience a gain and 11 a loss. But the largest loss, which is for Nigeria, is only \$0.6 million. By contrast, gains are as high as $\$ 167$ million for China. The gains for the rest of the world occur as a result of the additional liberalization from switching to the subsidy. ${ }^{10}$

The aggregate welfare gain of $\$ 4,354$ million adds nearly 10 percent to the gains that the model predicts from goods liberalization in the Doha Round without switching to a subsidy. Nonetheless, this is likely to be a low estimate of the cost of preferential trade agreements as a stumbling block for MTL because the focus here is on the preferences to least developed countries. The estimates in Limão (2006) suggest that the stumbling block effect is greater when it applies to several preferential trade agreements; if the additional liberalization was about 14 percentage points, the aggregate gains increase to more than $\$ 7$ billion, as shown in the last column of table 2. Even under the 8.3 percentage points scenario, the welfare estimates are likely to be a lower bound, for several reasons. First, they refer to an annual effect. With the static model used here, if there were no further shocks after the implementation of the subsidy scheme, the discounted welfare effect would be several times higher. Second, to calculate the welfare effects, we employed a static perfect competition model with no externalities, which is well known to provide relatively small gains from trade liberalization. Third, when the effect of the additional liberalization by the triad economies is computed, reciprocity effects are not added. In practice, the triad economies would be expected to attempt to negotiate further reductions from other countries. ${ }^{11}$

Since the additional liberalization of 8.3 percentage points is an estimate, the sensitivity of the results was tested by considering two extreme alternatives that represent its confidence interval: 2.8 percentage points and 14.3 percentage points. Two points stand out. First, most of the change in the aggregate gains, which now range from $\$ 2$ billion to $\$ 7$ billion, is due to the

10. For non-least developed countries, the estimates do not include the preference erosion effect caused by the extra 8.3 percent liberalization in the triad economy markets.

11. Under the preference scheme the MFN tariff reductions would result in a lower level of cooperation in nontrade issues by the small countries, which would entail an additional cost to the triad economies that is not computed here. 
triad economies-which is not surprising since they are the countries liberalizing. ${ }^{12}$ Second, the estimates for the least developed countries remain nearly unchanged because most of their gains arise from the avoided preference erosion under the 33 percent baseline reduction common to all three scenarios. Therefore, from the perspective of least developed countries, the proposal here should be attractive even if the amount of additional liberalization by the triad economies is very small. ${ }^{13}$

\section{Implementation, Scope, and Refinement of the Subsidy Scheme}

We analyzed the small budgetary cost of switching to the subsidy. The logistical costs of running it are similar to those for preferences because many of the procedures are already in place. However, we now discuss some potential differences in running each scheme and possible refinements to the subsidy proposal.

When the value of the subsidy and that of tariff rate are identical, they have equivalent effects on prices, quantities, and implementation. When the preferential tariff is zero, the exporter receives the domestic price in the preferencegranting country, $p^{\mathrm{w}}+t$, where $p^{\mathrm{w}}$ is the world price and $t$ is the MFN tariff, and $p^{\mathrm{w}}+t$ is also the price that the importer pays. Under the subsidy, the preferential exporter receives $p^{\mathrm{w}}+s$, the same as before when $t=s$. The importer pays $p^{\mathrm{w}}+t+s$ before receiving a rebate equivalent to the amount of the subsidy per unit, $s$. If this occurs at customs, the buyer's price is simply $p^{\mathrm{w}}+t$. Here, the subsidy is implemented as an immediate drawback scheme, which already exists in the triad economies to rebate import duties when the

12. The triad economies' total welfare change can be decomposed into an efficiency and a budgetary effect. The budgetary effect has two components: the first captures the cost of the subsidy relative to the preference under a 33 percent MFN tariff reduction (equation S.5 in the supplemental appendix), and the second captures the extra cost of the subsidy due to the additional liberalization (the term in the last parenthesis of equation S.8 in the supplemental appendix). The efficiency component is given by the remaining terms on the right side of equation (S.8). Under the intermediate scenario of an additional 8.3 percentage points, the first component of the budgetary cost accounts for 8 percent of the $\$ 2,934$ million welfare change of the triad economies. This increases to 14 percent for the total budgetary cost (14 percent for the EU, 5 percent for Japan, and 24 percent for the United States). Thus, most of the change in their welfare is driven by the efficiency effect.

13. To understand the insensitivity in the welfare effect for the least developed countries, note that it can be decomposed in two terms. As seen from equation (S.11) in the supplemental appendix, the first effect arises from the additional liberalization that occurs only under the subsidy, given by equation (S.10). The second effect is given by the second term in equation (S.11), which captures the difference in welfare changes under the subsidy versus the preference when tariffs fall by 33 percent. Under the preferences, a reduction in MFN tariffs causes a reduction in the welfare for the least developed countries because of erosion, as summarized in table 1. Thus, the second effect captures the role of the subsidy in avoiding preference erosion. In the estimates here this last effect dominates the effect from additional MTL by the triad economies, which accounts on average for only about 2 percent of the total welfare change for individual least developed countries. But there is some heterogeneity across countries in this, and for a few least developed countries, the effect from additional liberalization by the triad economies is actually negative because the additional MTL occurs in many goods, some of which the SRC may import. 
imported good is re-exported or used as an input in the production of an exported good.

The discussion above should also make clear that the subsidy is as transparent as the current preferences. Therefore, political economy arguments that the subsidy is more transparent, and thus less likely to be adopted, are not convincing. ${ }^{14}$

But the subsidy may become an issue after an MFN tariff reduction, that is, when $t^{\prime}<s$. Two differences arise when the MFN tariff rate falls. The first is the direct budgetary cost: customs collects $t^{\prime}$ per unit and must rebate $s$. Estimates show this cost is small. However, when the subsidies involve expenditure above the tariff collected on the product from that country, they may need to be in the budget. This could be financed directly from tariff revenue collected on imports from other countries. Moreover, from the domestic legal perspective of the SGC, the budget implications of subsidies are no different from those of the preferences. $^{15}$

The second issue that may arise when $t^{\prime}<s$ is re-exports. The buyer in the SGC can ship the good back to an agent in the SRC that will re-export it to collect the subsidy again. This is profitable if the excess subsidy, $s-t^{\prime}$, is high enough to offset the transaction cost, which includes the cost of forging the certificate of origin of the good and the two-way transport cost. For most goods, though, transport costs make re-exporting unprofitable, particularly when the origin country is a least developed country, where transport costs tend to be higher (Limão and Venables 2001). If interest forgone on the sale of the good because of the time in shipment is added, re-exports are very unlikely to be profitable. If re-exports became a problem, one solution would be to implement the subsidy rebate only when the good is sold to the final consumer in the SGC. Since internal sales often incur a sales tax, this would serve as an additional hurdle that would have to be overcome for re-exports to be profitable. In fact, exempting imports from least developed countries from

14. One political problem that governments in SGCs may face is justifying to the import competing producers why they are subsidizing a foreign producer. This is not an issue before the MFN tariff reduction since $t=s$ and so the subsidy is offset by the tariff. But it may be an issue after an MFN reduction, that is, when $t^{\prime}<s$. This should not be an issue if the MFN reduction was given since the SRCs we consider are small and so the domestic price in the SGC would remain almost unchanged for a given reduction in the MFN tariff under the preference or subsidy. So import competing producers would only oppose the subsidy if indeed the subsidy led to additional MFN liberalization. But this opposition is exactly identical to the import competing sector's opposition to MFN liberalization that arises because of other motives. The countervailing force here is therefore the same: exporters in each of the triad countries would support the subsidy precisely because it allows additional MTL in the remaining triad markets to which they export.

15. In the United States, for example, any foregone tariff revenue from a new preference must be estimated and a replacement in the budget suggested. There are also precedents for the use of import subsidies in the Eu-for example, when supplies of sugar available within the Community or a major consuming region are no longer sufficient (Council Regulation 1260/2001, June 19, 2001). 
paying such a tax could, under certain conditions, mimic the subsidy and thus be an alternative. ${ }^{16}$

This proposal may apply better to certain countries that are "strategically large," that is, whose cooperation in certain nontrade issues is important. Proposals for a "buy-out" of preferences, either through a lump-sum payment or temporary adjustment assistance through grants (Hoekman 2004) or loans (IMF 2004a and 2004b), are unlikely to work for those countries. ${ }^{17}$ For example, the United States had the opportunity to offer only cash for Colombia's cooperation on the war on drugs, and it chose not to. However, the skeptics of the subsidy scheme may want to first experiment by switching only in one sector or a subset of one sector. For example, there may be a stronger case for U.S. preferences to Colombia in the agricultural sector as a way to provide alternatives to growing coca. Moreover, sector-specific experimentation can show whether unexpected implementation problems may arise.

Choosing a fixed subsidy rate equal to the current preference margin yields a convenient benchmark to evaluate the welfare effects of a switch. But alternative subsidy rates can help address other problems with preferences. Preferences may have led to investment in sectors where countries do not have a comparative advantage (Tangermann 2002). A modified subsidy scheme would address this. A fixed subsidy rate that is equal for all products exported to all sGCs could be used to align the pattern of export specialization with relative world prices. This would keep relative prices in the SRC equal to world relative prices.

\section{Conclusion}

The recent wave of preferential trade agreements suggests that policymakers find them desirable. But their effect on multilateral liberalization must be estimated and taken seriously. This article describes recent theoretical and empirical evidence that shows how preferential trade agreements can slow multilateral liberalization even when the countries receiving the preference are small. It argues that import subsidies can be used to decouple preferences from MFN tariff liberalization and that subsidies would be supported by the countries receiving and granting preferences.

16. A sufficient condition for this exemption to work exactly in the same way as a subsidy rate of value $s$ is for the existing sales tax rate to be at least as high as the subsidy rate. This condition is not satisfied for some goods with high preference margins (which were chosen as the initial subsidy rate).

17. The IMF's proposed program is in the form of loans to finance temporary adjustment costs if the MFN tariff reductions have a significant effect on the balance of payments in the beneficiary countries. Even if this program compensated for the full amount of preference erosion, it would not be able to deliver the same MFN tariff reduction as the subsidy proposed because after the MFN tariff reduction the granting countries can only threaten to remove a smaller amount of preferences. Thus, they will be able to extract less in the form of side conditions than before the MFN reduction (or subsidy scheme). This implies that the granting countries themselves will offer fewer MFN reductions under the IMF program than under the subsidy scheme. 
We provide the first estimates of the welfare costs of preferential trade agreements as a stumbling block to multilateral liberalization. It is $\$ 2,934$ million per year for the TRIAD if they switched their preferences to least developed countries into fixed import subsidies in the context of the liberalization anticipated in the Doha Round. This occurs because under the subsidy plan triad economies can further reduce their MFN tariffs. The switch would also increase annual welfare in the rest of the world by $\$ 900$ million. For least developed countries receiving preferences from the triad economies, the gain is $\$ 520$ million—due mostly to the preference erosion avoided under the subsidy.

The aggregate annual welfare estimate of more than $\$ 4$ billion adds about 10 percent to the gains that the model predicts from goods liberalization in the Doha Round. This is likely to be a lower bound of the stumbling block effect of preferential trade agreements. At one extreme, the concern with preference erosion could prevent the completion of the round, costing an additional $\$ 47$ billion a year.

In terms of implementation, the budgetary costs of the subsidy are small, and the logistical costs are in principle not significantly higher than those associated with the current preferences. However, two issues must be addressed: legality in the wто and the scope of the subsidies. From a legal perspective the subsidies conflict with the MFN principle; but this could be addressed in the same way as preferences: through waivers, the enabling clause, or article XXIV, for example.

In terms of the scope of the subsidy, the question is whether the proposal should extend to all countries that receive unilateral preferences. The basic argument should apply to them as well. Naturally, the budgetary cost for the triad economies would be higher, but the additional MFN tariff liberalization that would result may be enough to offset it. Even more broadly, extending the scheme to members of all preferential trade agreements could be considered. The concern with preference erosion also applies to them, and there is evidence that they have slowed U.S. and EU MFN tariff liberalization. Future research should address this broader question and calculate the welfare costs of other preferential trade agreements.

\section{APPENDix}

First a simplified version of the model in Limão (2002) is presented to show how unilateral preferences to small countries can cause economies such as the EU and the United States to maintain higher multilateral tariffs and how this incentive disappears when an import subsidy is allowed. The role of side conditions in preferential trade agreements is then discussed.

\section{Preferences to Small Countries as a Stumbling Block to MTL}

Assume each regional bloc contains a large and a small country, denoted by $\mathrm{L}$ and S. Two externalities exist within each bloc. First, L is affected by the level of 
an action $e$ that $S$ can undertake at a cost. This is a general way to capture the demand that $\mathrm{L}$ has for cooperation in labor, environmental, immigration issues, improvements in governance, and so on. Second, there is a terms of trade externality, that is, L can use a tariff to depress the price of S's exports. Countries in a bloc can internalize these effects through a preferential trade agreement where L lowers its tariffs on S's exports in exchange for an increase in S's provision of $e$. The preferential trade agreement is modeled so that its only direct trade effect is to increase the price that $S$ receives for its exports.

There are two import tariffs that L chooses: $t$, the multilateral tariff that it applies to the rest of the world, and $t^{\mathrm{p}} \leq t$, the preferential tariff on that good applied to imports from $S$. The good that $L$ exports to the rest of the world faces a tariff $t^{\mathrm{r}}$. So the objective function that $\mathrm{L}$ maximizes is

$$
W^{\mathrm{L}}=W^{\mathrm{L}}\left(e, t^{\mathrm{p}}, t, t^{\mathrm{r}}\right)
$$

where the partial effects are $W_{e}^{\mathrm{L}}>0$ and, due to the terms of trade effects, $W_{x}^{\mathrm{L}}>0$ for $x=t^{\mathrm{p}}, t$ when evaluated at $x=0$ and $W_{t^{\mathrm{r}}}^{\mathrm{L}}<0$.

The objective maximized by $\mathrm{S}$ depends on $e$ and the tariffs set by $\mathrm{L}$, which affect the price that $S$ receives for its exports.

$$
W^{\mathrm{S}}=W^{\mathrm{S}}\left(e, t^{\mathrm{p}}, t\right)
$$

Under a preferential trade agreement $S$ receives an export price of $p^{\mathrm{w}}(t)+t-t^{\mathrm{p}}$, where $p^{\mathrm{w}}(t)$ is the equilibrium world price, so $p^{\mathrm{w}}(t)+t$ is the price in L. Therefore, $W_{t^{\mathrm{p}}}^{S}<0$ and $W_{t}^{S}>0$. But in the absence of a preferential trade agreement, $S$ faces the multilateral tariff and receives only $p^{\mathrm{w}}(t)$, which falls when $t$ is raised and so $W_{t}^{S}<0$. For simplicity, it is assumed that $S$ has no trade in the good exported by $\mathrm{L}$ to the rest of the world and thus is indifferent to the level of $t^{\mathrm{r}}$. The balance of payments condition is satisfied through a numeraire good that enters utilities in a quasi-linear way and that $\mathrm{L}$ uses to pay for its imports from $\mathrm{S}$.

The crucial assumption that generates a motive for L's preferential treatment for $S$ is that it values $e$. Take the neutral case where $S$ places neither a positive nor a negative weight on the direct effect of $e$ on itself and assume that this action requires some expenditure by $S$, which implies a negative marginal benefit in terms of the numeraire. So, if $S$ and $L$ do not cooperate, $S$ does not supply $e$ and $\mathrm{L}$ does not provide a preference. They can improve on this outcome through a bargain where $\mathrm{L}$ sets $t^{\mathrm{P}}<t$ and $\mathrm{S}$ supplies $e .^{18}$

18. Note that for a given $t$, this bargain may be just as efficient as a lump-sum transfer from $\mathrm{L}$ assuming that preferences are quasi-linear so that the tariff revenue that $\mathrm{L}$ gives up through the preference has the same effect as an equivalent lump-sum transfer. This would not be the case if $S$ had an upward sloping export supply as assumed in the simulation. However, there can be realistic political economy constraints that would deliver the preference instead of the lump-sum transfer as the constrained first-best policy to be used in exchange for $e$; here, it is simply assumed that the preference is the only available instrument, and the implications for the multilateral tariff are then analyzed. 
In most of the agreements analyzed here L has nearly all the bargaining power relative to $S$. Therefore, it is sensible to focus on the outcome of a take-it-or-leave-it offer that leaves $S$ at the status quo welfare level. If $S$ is a WTO member, the maximum tariff that $\mathrm{L}$ can set is $t^{\mathrm{p}}=t$, due to the MFN rule. Therefore, the status quo welfare will be determined by evaluating $t^{\mathrm{p}}$ at $t$ and $e$ at the level that is optimal for S. More specifically, the bargain that L offers must at least satisfy $W^{\mathrm{S}}\left(e=e^{\mathrm{b}}, t^{\mathrm{p}}=t^{\mathrm{b}}<t, t\right) \geq W^{\mathrm{S}}\left(e=0, t^{\mathrm{p}}=t, t\right)$. So for a given level of $t$ and $t^{\mathrm{p}}$, the equilibrium level of $e^{\mathrm{b}}$ can be written as a function $e^{\mathrm{b}}\left(t^{\mathrm{p}}, t\right)$ that is decreasing in the preferential tariff and increasing in the MFN tariff because either movement raises $W^{S}$ and thus allows $\mathrm{L}$ to extract a higher level of $e$. In the simple case the focus is on the fact that net exports of $S$ are constant, implying that, in the function $e^{\mathrm{b}}\left(t^{\mathrm{p}}, t\right), \mathrm{S}$ cares only about the preferential margin $t-t^{\mathrm{p}}$, so $e_{t}^{\mathrm{b}}=-e_{t^{\mathrm{p}}}^{\mathrm{b}}>0$.

WTO countries negotiate reciprocal tariff reductions with their principal suppliers. So if the rest of the world (ROW) is the main supplier of the good that $\mathrm{L}$ also imports from S, L negotiates with ROW. To capture this, the equilibrium multilateral tariffs are modeled as the solution that maximizes the joint objective of $\mathrm{L}$ and ROW. Moreover, it is assumed that $\mathrm{L}$ chooses the preferential tariff simultaneously and that ROW is a mirror image of L, although neither of these assumptions is essential for the result. This implies that the focus can be on solving for $t$, since it will be equal to $t^{\mathrm{r}}$, and that the effect of $t$ on $W^{\mathrm{r}}$ is identical to that of $t^{\mathrm{r}}$ on $W^{\mathrm{L}}$. Imposing the equilibrium conditions of symmetry, $t=t^{\mathrm{r}}$, and $e=e^{\mathrm{b}}\left(t^{\mathrm{p}}, t\right)$ the joint optimum for $\mathrm{L}$ and ROW under a preferential trade agreement is given by the following program and necessary first-order conditions

$$
\left\{\tilde{t}, \tilde{t}^{\mathrm{p}}\right\} \equiv \arg _{t, t^{\mathrm{p}}} \max W^{\mathrm{L}}\left(e=e^{\mathrm{b}}\left(t^{\mathrm{p}}, t\right), t^{\mathrm{p}}, t, t^{\mathrm{r}}=t\right)
$$

$$
W_{t^{\mathrm{p}}}^{\mathrm{L}}+W_{e}^{\mathrm{L}} e_{t^{\mathrm{p}}}^{\mathrm{b}} \leq 0
$$

To see how a stumbling block can arise when import subsidies are not allowed, let us constrast this with the condition for the tariff in the absence of a preferential trade agreement. Now $\mathrm{L}$ has no incentive to provide a preference to $\mathrm{S}$, so $t=t^{\mathrm{p}}$ and $e=0$, which yields the following solution:

$$
t^{\prime} \equiv \arg _{t} \max W^{\mathrm{L}}\left(e=0, t^{\mathrm{p}}=t, t, t^{\mathrm{r}}=t\right)
$$

Using the first-order condition derived for this last problem, $W_{t}^{\mathrm{L}}+W_{t^{\mathrm{r}}}^{\mathrm{L}}+W_{t^{\mathrm{p}}}^{\mathrm{L}}=0$, to evaluate the first-order condition for $t$ when a preferential trade agreement is present (equation A.5), it can be determined whether $\tilde{t}>t^{\prime}$. That will be so if the following expression is positive: 


$$
\begin{aligned}
\left(W_{t}^{\mathrm{L}}+W_{t^{\mathrm{r}}}^{\mathrm{L}}+W_{e}^{\mathrm{L}} e_{t}^{\mathrm{b}}\right)_{t^{\prime}, t^{\mathrm{p}}=0} & \geq\left[W_{t}^{\mathrm{L}}+W_{t^{\mathrm{r}}}^{\mathrm{L}}+W_{t^{\mathrm{p}}}^{\mathrm{L}}\left(-\frac{e_{t}^{\mathrm{b}}}{e_{t^{\mathrm{p}}}^{\mathrm{b}}}\right)\right]_{t^{\prime}, t^{\mathrm{p}}=0} \\
& =\left\{\left(W_{t}^{\mathrm{L}}+W_{t^{\mathrm{r}}}^{\mathrm{L}}\right)\left[1-\left(-\frac{e_{t}^{\mathrm{b}}}{e_{t^{\mathrm{p}}}^{\mathrm{b}}}\right)\right]\right\}_{t^{\prime}, \mathrm{p}^{\mathrm{p}}=0}=0
\end{aligned}
$$

where the inequality in the first line reflects the use of equation (A.4). If import subsidies were allowed, $t^{\mathrm{p}}$ could continue to be lowered below zero and the inequality above would disappear since an interior solution could be found. But otherwise it is possible to obtain a corner solution in the preferential trade agreement, that is a situation where, at $t^{\mathrm{p}}=0, \mathrm{~L}$ would like $\mathrm{S}$ to increase $e$. In this case, equation (A.4) holds with a strict inequality. The second line of equation (A.7) is zero in the case considered here, where $-e_{t^{\mathrm{p}}}^{\mathrm{b}}=e_{t}^{\mathrm{b}}$-that is, when an increase in the MFN tariff has the same effect as a decrease in the preferential tariff, both simply increase the preferential margin. This implies that $\tilde{t}>t^{\prime}$ if $\left[W_{t^{\mathrm{p}}}^{\mathrm{L}}+W_{e}^{\mathrm{L}} e_{t_{\mathrm{p}}}^{\mathrm{b}}\right]_{t \mathrm{p}=0}<0$. So import subsidies completely eliminate the need to distort the MFN tariff to maintain a preference margin.

\section{Side Conditions in Preferential Agreements}

The Generalized System of Preferences and other unilateral preferences provided by the EU and United States often have side conditions attached that are valued by the preference-granting country and potentially costly to the recipient. That is, these unilateral preferences are not free to developing countries. The Generalized System of Preferences, for example, was designed to promote the development of poorer countries based on an infant industry argument (UNCTAD 1964), but "during the last twenty-five years or so the experience of the GSP in the GATT system has been that for a number of reasons the preference-granting national entities (that is, the industrialized countries) often succumb to the temptation to use the preference systems as part of 'bargaining chips' of diplomacy” (Jackson 1997, p. 160). International trade lawyers have also warned of the possibility that the Generalized System of Preferences will retard the MTL of the developed countries that grant such preferences because of a similar mechanism (Trebilcock and Howse 1999). Failure of Generalized System of Preferences beneficiaries to comply with some of the nontrade issues has cost them their preferential access to the United States. ${ }^{19}$

19. For example, according to USTR (2005), some countries have lost eligibility for trade preferences under Generalized System of Preferences because of worker rights or intellectual property concerns. In 2005 the United States revoked Côte d'Ivoire's eligibility for trade preferences under the African Growth and Opportunity Act because it failed to comply with the U.N. cease fire resolution. Morocco enacted a comprehensive new labor law recently, and according to U.S. trade negotiators, it was "the prospect of a free trade agreement with the United States [that] helped to forge a domestic consensus for labor law reform in Morocco, spurring reform efforts that had been stymied for more than 20 years" (USTR 2004). 
Both the EU and the United States explicitly offer reductions in trade barriers in exchange for cooperation on various nontrade issues such as labor, environment, drug trafficking, and intellectual property protection. Examples of these have included the Eastern European and Mediterranean agreements signed by the EU; the U.S. agreements with Jordan, Mexico, and other Latin American and Caribbean countries; and the preferential treatment that the EU and the United States extend to most developing countries through Generalized System of Preferences. This type of agreement is increasingly prevalent, as the new U.S. preferences to Middle Eastern countries make clear. ${ }^{20}$

Table A.1. Preference Erosion and Subsidy by Beneficiary Country (\$ Millions)

\begin{tabular}{|c|c|c|c|c|c|c|}
\hline \multirow[b]{2}{*}{$\begin{array}{l}\text { Subsidy-Receiving } \\
\text { Country }\end{array}$} & \multicolumn{2}{|c|}{ European Union } & \multicolumn{2}{|c|}{ Japan } & \multicolumn{2}{|c|}{ United States } \\
\hline & $\begin{array}{l}\text { Preference } \\
\text { Erosion }\end{array}$ & Subsidy & $\begin{array}{l}\text { Preference } \\
\text { Erosion }\end{array}$ & Subsidy & $\begin{array}{l}\text { Preference } \\
\text { Erosion }\end{array}$ & Subsidy \\
\hline Afghanistan & 0.28 & 0.64 & 0.00 & 0.00 & 0.00 & 0.00 \\
\hline Angola & 3.08 & 4.10 & 0.07 & 0.20 & 0.00 & 0.00 \\
\hline Bangladesh & 193.61 & 346.86 & 6.55 & 11.17 & 1.90 & 2.48 \\
\hline Benin & 0.61 & 1.19 & 0.00 & 0.00 & 0.00 & 0.00 \\
\hline Bhutan & 0.04 & 0.11 & 0.00 & 0.00 & 0.01 & 0.01 \\
\hline Burkina Faso & 0.55 & 1.19 & 0.00 & 0.00 & 0.00 & 0.01 \\
\hline Burundi & 0.03 & 0.05 & 0.00 & 0.00 & 0.00 & 0.00 \\
\hline Cambodia & 20.80 & 41.74 & 5.40 & 10.76 & 0.17 & 0.33 \\
\hline Cape Verde & 0.37 & 0.75 & 0.00 & 0.00 & 0.07 & 0.15 \\
\hline $\begin{array}{l}\text { Central African } \\
\text { Republic }\end{array}$ & 0.56 & 0.79 & 0.00 & 0.00 & 1.55 & 0.85 \\
\hline Chad & 0.02 & 0.07 & 0.00 & 0.00 & 0.00 & 0.00 \\
\hline Comoros & 0.04 & 0.10 & 0.00 & 0.00 & 0.00 & 0.00 \\
\hline Congo & 0.27 & 0.47 & 0.00 & 0.01 & 0.01 & 0.02 \\
\hline Djibouti & 0.05 & 0.11 & 0.00 & 0.00 & 0.00 & 0.00 \\
\hline Equatorial Guinea & 0.02 & 0.04 & 0.00 & 0.00 & 0.00 & 0.00 \\
\hline Eritrea & 0.29 & 0.45 & 0.00 & 0.00 & 0.00 & 0.00 \\
\hline Ethiopia & 0.87 & 2.04 & 0.03 & 0.06 & 0.06 & 0.18 \\
\hline Gambia, The & 0.58 & 0.87 & 0.05 & 0.08 & 0.00 & 0.01 \\
\hline Guinea & 2.59 & 3.27 & 0.00 & 0.00 & 0.03 & 0.04 \\
\hline Guinea-Bissau & 0.22 & 0.25 & 0.00 & 0.00 & 0.00 & 0.00 \\
\hline
\end{tabular}

(Continued)

20. See USITC $(1994,1996)$ for conditions applying to the Andean Trade Preference Act. See Bayard and Elliot (1994) and UNCTAD (2000) for details on conditionality in the Generalized System of Preferences program. See Perroni and Whalley (2000) for details on conditionality in the North American Free Trade Agreement. See Winters (1993) for details on the Eu's Eastern European, Mediterranean, and Generalized System of Preferences programs; the Generalized System of Preference programs are also described in UNCTAD (2002). 
Table A.1. Continued

\begin{tabular}{|c|c|c|c|c|c|c|}
\hline \multirow[b]{2}{*}{$\begin{array}{l}\text { Subsidy-Receiving } \\
\text { Country }\end{array}$} & \multicolumn{2}{|c|}{ European Union } & \multicolumn{2}{|c|}{ Japan } & \multicolumn{2}{|c|}{ United States } \\
\hline & $\begin{array}{l}\text { Preference } \\
\text { Erosion }\end{array}$ & Subsidy & $\begin{array}{l}\text { Preference } \\
\text { Erosion }\end{array}$ & Subsidy & $\begin{array}{l}\text { Preference } \\
\text { Erosion }\end{array}$ & Subsidy \\
\hline Haiti & 0.23 & 0.37 & 0.01 & 0.01 & 1.08 & 2.61 \\
\hline Kiribati & n.a. & n.a. & n.a. & n.a. & n.a. & n.a. \\
\hline Lao PDR & 6.77 & 13.02 & 0.12 & 0.30 & 0.00 & 0.00 \\
\hline Lesotho & 0.25 & 0.29 & 0.00 & 0.00 & 22.90 & 18.78 \\
\hline Liberia & 0.79 & 2.27 & 0.00 & 0.00 & 0.01 & 0.02 \\
\hline Madagascar & 45.42 & 63.52 & 0.08 & 0.15 & 18.14 & 15.18 \\
\hline Malawi & 40.77 & 39.64 & 0.01 & 0.01 & 110.28 & 25.42 \\
\hline Maldives & 3.84 & 4.31 & 0.03 & 0.04 & 0.00 & 0.00 \\
\hline Mali & 1.22 & 1.58 & 0.00 & 0.01 & 0.03 & 0.05 \\
\hline Mauritania & 5.91 & 8.75 & 1.28 & 2.60 & 0.00 & 0.00 \\
\hline Mozambique & 11.17 & 14.21 & 0.00 & 0.00 & 0.02 & 0.04 \\
\hline Myanmar & 20.55 & 37.85 & 1.79 & 3.59 & 0.12 & 0.33 \\
\hline Nepal & 4.78 & 11.55 & 0.72 & 1.88 & 0.37 & 0.62 \\
\hline Niger & 0.48 & 0.90 & 0.00 & 0.01 & 0.02 & 0.04 \\
\hline Rwanda & 0.03 & 0.09 & 0.00 & 0.00 & 0.00 & 0.01 \\
\hline Samoa & 0.03 & 0.04 & 0.02 & 0.02 & 0.00 & 0.01 \\
\hline São Tomé and Principe & 0.77 & 0.93 & 0.00 & 0.00 & 0.00 & 0.01 \\
\hline Senegal & 19.68 & 28.41 & 0.06 & 0.13 & 0.02 & 0.05 \\
\hline Sierra Leone & 5.33 & 11.27 & 0.00 & 0.00 & 0.02 & 0.04 \\
\hline Solomon Islands & 2.01 & 2.14 & 0.20 & 0.34 & 0.00 & 0.00 \\
\hline Somalia & 0.04 & 0.06 & 0.00 & 0.00 & 0.01 & 0.02 \\
\hline Sudan & 0.84 & 1.41 & 0.00 & 0.01 & 0.00 & 0.00 \\
\hline Tanzania & 28.22 & 30.98 & 0.04 & 0.09 & 8.29 & 3.15 \\
\hline Togo & 0.55 & 0.96 & 0.00 & 0.00 & 0.01 & 0.04 \\
\hline Tuvalu & 0.02 & 0.04 & 0.00 & 0.00 & 0.00 & 0.00 \\
\hline Uganda & 8.12 & 7.82 & 0.00 & 0.00 & 0.01 & 0.03 \\
\hline Vanuatu & 0.03 & 0.08 & 0.08 & 0.17 & 0.01 & 0.02 \\
\hline Yemen & 1.12 & 1.42 & 0.02 & 0.04 & 0.00 & 0.00 \\
\hline Zambia & 6.38 & 9.72 & 0.00 & 0.00 & 0.40 & 0.63 \\
\hline
\end{tabular}

n.a., not available.

Source: Authors' calculations based on data discussed in the supplemental appendix.

Table A.2. Changes in Net Welfare by Least Developed Countries

\begin{tabular}{lccc}
\hline Subsidy-Receiving Country & Total(\$ Millions) & Per Capita $(\$)$ & Share of $\operatorname{GDP}^{\mathrm{a}}(\%)$ \\
\hline Afghanistan & 0.26 & 0.01 & 0.01 \\
Angola & 2.59 & 0.2 & 0.02 \\
Bangladesh & 175.72 & 1.31 & 0.36 \\
Benin & 0.53 & 0.08 & 0.02 \\
Bhutan & 0.05 & 0.06 & 0.01 \\
Burkina Faso & 0.48 & 0.04 & 0.02 \\
\hline
\end{tabular}


TABLE A.2. Continued

\begin{tabular}{|c|c|c|c|}
\hline Subsidy-Receiving Country & Total(\$ Millions) & $\operatorname{Per} \operatorname{Capita}(\$)$ & Share of $\operatorname{GDP}^{\mathrm{a}}(\%)$ \\
\hline Burundi & 0.01 & 0 & 0 \\
\hline Cambodia & 23.55 & 1.8 & 0.6 \\
\hline Cape Verde ${ }^{\mathrm{b}}$ & 0.4 & 0.88 & 0.06 \\
\hline Central African Republic & 1.67 & 0.44 & 0.16 \\
\hline Chad & 0.01 & 0 & 0 \\
\hline Comoros $^{\mathrm{b}}$ & 0.04 & 0.07 & 0.02 \\
\hline Congo, Rep. & 0.19 & 0.05 & 0.01 \\
\hline Djibouti & -0.07 & -0.1 & -0.01 \\
\hline Equatorial Guinea & 0.01 & 0.02 & 0 \\
\hline Eritrea & 0.25 & 0.06 & 0.04 \\
\hline Ethiopia & 0.87 & 0.01 & 0.01 \\
\hline Gambia, The ${ }^{\mathrm{b}}$ & 0.55 & 0.4 & 0.14 \\
\hline Guinea & 2.21 & 0.29 & 0.07 \\
\hline Guinea-Bissau & 0.17 & 0.12 & 0.08 \\
\hline Haiti $^{\text {b }}$ & 0.78 & 0.1 & 0.02 \\
\hline Kiribati & n.a. & n.a. & n.a. \\
\hline Lao PDR & 6.16 & 1.13 & 0.34 \\
\hline Lesotho $^{\mathrm{b}}$ & 18.14 & 10.26 & 2.09 \\
\hline Liberia & 0.78 & 0.24 & 0.15 \\
\hline Madagascar & 53.06 & 3.27 & 1.16 \\
\hline Malawi & 116.94 & 11 & 6.66 \\
\hline Maldives & 3.05 & 10.76 & 0.47 \\
\hline Mali & 1.01 & 0.09 & 0.03 \\
\hline Mauritania & 6.13 & 2.36 & 0.61 \\
\hline Mozambique & 9.47 & 0.52 & 0.25 \\
\hline Myanmar & 19.96 & 2.6 & 1.23 \\
\hline Nepal & 5.43 & 0.23 & 0.1 \\
\hline Niger & 0.45 & 0.04 & 0.02 \\
\hline Rwanda & 0.01 & 0 & 0 \\
\hline Samoa ${ }^{b}$ & 0.05 & 0.29 & 0.02 \\
\hline São Tomé and Principe & 0.65 & 4.26 & 1.32 \\
\hline Senegal & 17.06 & 1.73 & 0.33 \\
\hline Sierra Leone & 4.83 & 0.93 & 0.65 \\
\hline Solomon Islands & 1.84 & 4.21 & 0.67 \\
\hline Somalia & 0.04 & 0 & 0 \\
\hline Sudan & 0.53 & 0.02 & 0 \\
\hline Tanzania & 29.82 & 0.86 & 0.32 \\
\hline Togo & 0.53 & 0.11 & 0.04 \\
\hline Tuvalu & 0.01 & 0 & 0 \\
\hline Uganda & 6.65 & 0.27 & 0.11 \\
\hline Vanuatu & 0.08 & 0.39 & 0.03 \\
\hline Yemen, Rep. & 0.84 & 0.05 & 0.01 \\
\hline Zambia & 5.95 & 0.59 & 0.16 \\
\hline
\end{tabular}

n.a., not available.

${ }^{\mathrm{a}} \mathrm{GDP}$ is for 2002 and in current U.S. dollars.

${ }^{b}$ Excludes changes in tariff revenue due to the lack of tariff data. The direction of the bias is unclear, but it is probably small since changes in tariff revenue represent on average less than 1 percent of the total welfare change. 


\section{REFERENCES}

Adam, C., and S. O’Connell. 2004. “Aid versus Trade Revisited.” The Economic Journal 114:150-73.

Bagwell, K., and R. Staiger. 1998. "Regionalism and Multilateral Tariff Cooperation.” In J. Piggott and A. Woodland, eds., International Trade Policy and the Pacific Rim. London: MacMillan.

Bayard, T., and K. Ann Elliott. 1994. Reciprocity and Retaliation in US Trade Policy. Washington, D.C.: Institute for International Economics.

Bhagwati, J. 1991. The World Trading System at Risk. Princeton, N.J.: Princeton University Press.

Chang, W., and A. Winters. 2002. "How Regional Blocs Affect Excluded Countries: The Price Effects of Mercosur.” American Economic Review 92(4):889-904.

European Commission. 2000. "Commission Proposes Overhaul of Sugar Market.” IP/00/1109, April 10. Brussels.

Francois, J. H. van Mejil, and F. van Tongeren. 2005. "Trade Liberalization in the Doha Development Round.” Economic Policy 20(42):349-39.

Haveman, J., and H. Shatz. 2004. "Developed Country Trade Barriers and the Least Developed Countries: The Economic Results of Freeing Trade.” In B. Guha-Khasnobis, ed., The wTo, Developing Countries and the Doha Development Agenda. New York: Palgrave-MacMillan.

Hoekman, B. 2004. "Overcoming Discrimination against Developing Countries: Access, Rules and Differential Treatment." Paper presented at the Cornell Law School and Cordell Hull Institute conference "The Role of the wTO System in the World Economy," July 9-10, Paris.

Hoekman, B., C. Michalopoulos, and A. Winters. 2004. "Special and Differential Treatment of Developing Countries in the wTO: Moving Forward after Cancun.” The World Economy 27(4):481-506.

Hoekman, B., A. Nicita, and M. Olarreaga. 2006. "Estimating the Effects of Global Trade Reform." In B. Hoekman and M. Olarreaga, eds., Global Trade Liberalization and Poor Countries: Poverty Impacts and Policy Implications. Washington D.C.: Brookings Institution Press, and Paris: Institut de Sciences Politiques.

IMF (International Monetary Fund). 2004a. "Fund Support for Trade-Related Balance of Payments Adjustments." Policy Development and Review Department, Washington, D.C. [http://www. imf.org/external/np/pdr/tim/2004/eng/022704.pdf].

2004b. “IMF Executive Board Approves Trade Integration Mechanism.” Press Release 04/73, April 13. Washington, D.C.

Inama, S. 2003. "Trade Preferences and the World Trade Organization Negotiations on Market Access.” Journal of World Trade 37(5):959-76.

Jackson, J. 1997. The World Trading System: Law and Policy of International Economic Relations. Second edition. Cambridge, Mass.: MIT Press.

Johnson, Harry G. 1967. Economic Policies toward Less Developed Countries. Washington, D.C.: Brookings Institution.

Karacaovali, B., and N. Limão. 2005. "The Clash of Liberalizations: Preferential vs. Multilateral Trade Liberalization in the European Union.” Policy Research Working Paper 3493. World Bank, Washington,D.C.

Kee, H. L., A. Nicita, and M. Olarreaga. 2004. "Import Demand Elasticities and Trade Distortions.” Policy Research Working Paper 3452. World Bank, Washington, D.C.

Krishna, P. 1998. "Regionalism and Multilateralism: A Political Economy Approach.” Quarterly Journal of Economics 113(1):227-51.

Levy, P. 1997. “A Political-Economic Analysis of Free-Trade Agreements.” American Economic Review 87(4):506-19.

Limão, N. 2002. “Are Preferential Trade Agreements with Non-trade Objectives a Stumbling Block for Multilateral Liberalization?” Working Paper 02-02. University of Maryland, Department of Economics, Center for International Economics, College Park.

_. 2006. "Preferential Trade Agreements as Stumbling Blocks for Multilateral Trade Liberalization: Evidence for the US." American Economic Review. 
Limão, N., and A. Venables. 2001. "Infrastructure, Geographical Disadvantage, Transport Costs and Trade." World Bank Economic Review 15(2):451-79.

McCulloch, R., and J. Pinera. 1977. "Trade as Aid: The Political Economy of Tariff Preferences for Developing Countries." American Economic Review 67(5):959-67.

Mendelowitz, Allan. 1994. "International Trade: Issues Concerning the Generalized System of Preferences.” GAO/T-GGD-94-174, June 20. U.S. General Accounting Office, Washington, D.C.

OECD (Organisation for Economic Co-operation and Development). 2003. Tariffs and Trade: OECD Query and Simulation Package. Paris.

Panitchpakdi, Supachai. 2004. "Dr. Supachai Lauds IMF’s New Policy.” Statement before International Monetary and Financial Committee, April 24, Washington, D.C.

Perroni, C., and J. Whalley. 2000. "The New Regionalism: Trade Liberalization or Insurance?” Canadian Journal of Economics 33(1):1-24.

Sapir, A. 1981. "Trade Benefits under the EEC Generalized System of Preferences.” European Economic Review 15(3):339-55.

Sapir, A., and L. Lundberg. 1984. "The US Generalized System of Preferences and Its Impacts.” In A.O. Krueger and R.E. Baldwin, eds., The Structure and Evolution of US Trade Policy. National Bureau of Economic Research Conference Report. Chicago, Ill.: University of Chicago Press.

Stevens, C., and J. Kennan. 2004. "Making Preferences More Effective." Briefing Paper. Institute of Development Studies, Brighton, U.K.

Subramanian, A. 2004. "Financing of Losses From Preference Erosion.” WT/TF/COH/14. Communication from the International Monetary Fund. World Trade Organization, Geneva.

Tangermann, S. 2002. "The Future of Preferential Trade Arrangements for Developing Countries and the Current Round of wTo Negotiations on Agriculture.” Rome: Food and Agriculture Organization.

Trebilcock, M. J., and R. Howse. 1999. The Regulation of International Trade. Second edition. New York: Routledge.

UnCTAD (United Nations Conference on Trade and Development). 1964. "Towards a New Trade Policy for Development.” Report by the Secretary-General of unCTAD. New York.

- 2000. "Generalized System of Preferences: Handbook on the Scheme of the USA." UNCTAD/ITCD/ TSB/Misc.58. Geneva.

. 2002. "Handbook on the Scheme of the European Community." UnCTAD/ITCD/TSB/Misc.25/ Rev.2. Geneva.

- 2003. "Trade Preferences for LDCs: An Early Assessment of Benefits and Possible Improvements.” UNCTAD/ITCD/TSB/2003/8. Geneva.

USITC (United States International Trade Commission). 1994. "Andean Trade Preference Act: Effect on the U.S. Economy and on Andean Drug Crop Eradication and Crop Substitution.” Washington D.C.

1996. "Andean Trade Preference Act: Effect on the U.S. Economy and on Andean Drug Crop Eradication and Crop Substitution." Washington, D.C.

USTR (Office of the United States Trade Representative). 2004. "Morocco FTA Leads to Progress on Labor Reform.” Fact sheet. Washington, D.C. [http://www.ustr.gov/Document_Library/Fact_Sheets/ 2004/Morocco_FTA_Leads_to_Progress_on_Labor_Reform.html].

- 2005. "U.S. Generalized System of Preferences Guidebook.” Washington, D.C. [http://www.ustr.gov/ assets/Trade_Development/Preference_Programs/GSP/asset_upload_file267_8359.pdf].

Winters, A. 1993. "Expanding EC Membership and Association Accords: Recent Experience and Future Prospects." In K. Anderson and R. Blackhurst, eds., Regional Integration and the Global Trading System. New York: St. Martin's Press.

- 1999. "Regionalism vs. Multilateralism.” In R. Baldwin, D. Cohen, A. Sapir, and T. Venables, eds., Market Integration, Regionalism and the Global Economy. Cambridge, U.K.: Centre for Economic Policy Research.

—. 2004. “Adjustment Assistance for Trade Liberalization.” World Bank, Washington, D.C. 